\title{
Methanogenesis from forages fed to sheep
}

\author{
G.C. WAGHORN, M.H. TAVENDALE and D.R. WOODFIELD \\ AgResearch Grasslands, Private Bag 11008, Palmerston North
}

garry.waghorn@agresearch.co.nz

\begin{abstract}
Methane production has been measured from lambs fed contrasting forages. This work has been driven by the need to reduce greenhouse gas emissions from agriculture and to determine energy losses to methane from contrasting diets. Young ram lambs were fed either fresh ryegrass/white clover pasture, lucerne (also pelleted lucerne), sulla, chicory, red clover, Lotus pedunculatus (lotus) and mixtures of sulla and lucerne, sulla and chicory and chicory with red clover. The effects of condensed tannin (CT) in lotus on methane production were also measured. The trials were carried out indoors with sheep held in metabolism crates to enable an accurate measurement of intake and digestibility as well as methane production.

Principal findings were a two-fold range in emissions from $11.5 \mathrm{~g} \mathrm{CH}_{4} / \mathrm{kg}$ dry matter intake (DMI) with lotus to $25.7 \mathrm{~g} \mathrm{CH}_{4} / \mathrm{kg}$ DMI with pasture and a $16 \%$ reduction in methane production due to the $\mathrm{CT}$ in lotus. This range in emissions from good quality forages represents a loss of about $7-11 \%$ of metabolisable energy and presents a clear direction for future research to better utilise the feeding value of pastures and reduce greenhouse gas (GHG) emissions from agriculture. High quality perennial forages should be used where practical, and researchers need to identify plant parameters responsible for the variation in methane emissions. Research must focus on rapid passage of digesta through the rumen of grazing animals and will involve manipulation of the fibre content of grasses. Introduction of CT into diets is a likely target to reduce methane production. Improving the rapidly digestible constituents of forages is another opportunity, but difficult to target.
\end{abstract}

Keywords: condensed tannins, forage quality, forages, greenhouse gases, methane emissions, sheep

\section{Introduction}

The role of greenhouse gases (GHG) in global warming and the need to reduce GHG emissions, especially methane, has received extensive media coverage during 2002 because of New Zealand's intention to ratify the Kyoto Protocol. Should a minimum of $55 \%$ of countries ratify the protocol (representing at least $55 \%$ of total emissions), New Zealand will be bound to reduce GHG emissions to 1990 levels or be liable for some form of penalty. This penalty will probably commence in 2008 .

The commitment to limiting GHG emissions has important implications for farmers. Approximately 55\% of total New Zealand GHG emissions arise from landbased industries, comprising about $70 \%$ from methane and $30 \%$ from nitrous oxides. Nearly all of New Zealand's methane comes from agriculture, of which $88 \%$ is from ruminant digestion (enteric fermentation) (New Zealand Climate Change Project, 2002). Both methane and nitrous oxide $\left(\mathrm{N}_{2} \mathrm{O}\right)$ have a higher global warming potential than carbon dioxide, so small changes in emissions from agriculture result in large changes in total GHG emissions. Primary industries also contribute to carbon dioxide emissions (e.g. from cultivation) but are able to sequester carbon (e.g. in forests). Carbon dioxide balance is not considered to be as important as methane and nitrous oxides in agriculture, both of which appear to be more amenable to reduction.

Although global warming and the potential financial penalties have been the main drivers behind GHG research, there are other reasons why the pastoral industries should support this work. The methane belched from ruminants fed forages typically represents about $10 \%$ of metabolisable energy (ME) intake, with a range from 7\% (Robertson \& Waghorn 2002) to about 17\% of ME when silage diets are fed (Woodward et al. 2001). The methane produced from a single dairy cow averages $250 \mathrm{~g} /$ day, or $91 \mathrm{~kg} /$ year (Clark 2001), which annually would be sufficient to power a medium-large car for $1,000 \mathrm{~km}$ ! Our vision should be to divert some of the energy lost as methane into animal products, so that efficiency of feed energy utilisation is improved together with a reduction in GHG emissions.

Measurements of methane production from cattle fed concentrate, mixed concentrate/forage and forage rations show a range in emissions (expressed as \% of feed gross energy (GE; combustible energy)) from about $3-11 \%$ of GE (Johnson et al. 2000). This range demonstrates the importance of feed type on energy loss to methane and provides an incentive to understand the basis of differences between feeds (for future selection of forages to lower methane) and to measure methane production from animals fed forages which are currently available. This paper summarises results from recent feeding trials where a range of diets have been given to sheep and suggests future plant breeding options.

\section{Methods}

Four separate experiments were carried out between 
November 2000 and February 2002, in which 10 contrasting diets were fed to groups of 6-8 sheep to measure methane production in conjunction with feed intake. The experiments have been defined as FMR (forage mixed ration) Trial 1, FMR Trial 2, lotus and dried lucerne (eg Tables 1 and 2). Each experiment involved groups of ram lambs aged between 6 and 15 months (separate groups for each feed type) held indoors in metabolism crates to facilitate accurate measurements of feed intake. All forages were cut daily except for the dried lucerne diet. FMR Trial 1 comprised measurements from sheep fed pasture (fresh ryegrass (Lolium perenne)/ white clover (Trifolium repens)) lucerne (Medicago sativa), sulla (Hedysarum coronarium) and a sulla/ lucerne mixture. Diets fed in TMR Trial 2 included sulla, chicory (Cichorium intybus), red clover (Trifolium pratense) and mixtures of chicory/sulla and chicory/red clover. Mixtures in both trials were on a 1:1 DM basis.
Table 1 Composition of diets eaten by young wether sheep used for measurement of methane production. Data are $\mathrm{g} / 100 \mathrm{~g}$ dry matter (DM) unless indicated.

\begin{tabular}{lccccc}
\hline Diet & DM\% & CP & NDF & NSC & CT \\
\hline FMR Trial 1' & & & & & \\
2Pasture (ryegrass/white clover) & 21.0 & 18.5 & 44.4 & 13.5 & 0 \\
Lucerne (Medicago sativa) & 18.5 & 24.0 & 31.4 & 15.2 & 0 \\
Sulla (Hedysarum coronarium) & 14.3 & 17.5 & 20.2 & 23.2 & 6.8 \\
'3 5 ulla/lucerne & 17.6 & 25.9 & 22.5 & 17.1 & 3.5 \\
FMR Trial 2 & & & & & \\
Chicory (Cichorium intybus) & 9.6 & 12.3 & 12.7 & 14.8 & 0 \\
Red clover (Trifolium pratense) & 17.0 & 24.4 & 34.2 & 11.1 & 0.3 \\
Sulla & 15.9 & 19.7 & 22.6 & 17.6 & 3.5 \\
${ }^{3}$ Chicory/Sulla & 12.4 & 15.5 & 20.9 & 12.1 & 1.4 \\
${ }^{3}$ Chicory/Red clover & 11.0 & 19.5 & 23.8 & 11.7 & 0.1 \\
& & & & & \\
Lotus (Lotus pedunculatus) & 11.6 & 26.4 & 29.3 & 11.3 & 5.3 \\
Dried lucerne & 88.0 & 22.0 & 35.2 & 1.5 & 0 \\
\hline
\end{tabular}

Abbreviations: $C P$, crude protein; NDF, neutral detergent fibre (hemicellulose + cellulose + lignin); NSC, non structural carbohydrate; CT, condensed tannin.

${ }^{1}$ Forage mixed ration trial conducted in 2000 (Burke et al. 2002) and in 2001 (Waghorn, unpublished).

${ }^{2}$ Pasture comprised (DM) 80:20 ryegrass (Lolium perenne): white clover (Trifolium repens).

${ }^{3}$ Mixtures were fed on a 50:50 (DM) basis.
The Lotus pedunculatus (lotus) diet was used to determine effects of CT on methane production. Effects of CT were demonstrated by giving one group of sheep twice daily doses of polyethylene glycol (PEG; $80 \mathrm{~g}$ per day as a $50 \%$ aqueous solution) to bind with and remove effects of CT (Jones \& Mangan 1977) throughout the trial. Dried and pelleted lucerne (with $15 \%$ of chaffed lucerne hay) was fed in the fourth experiment

The sheep were fed the diets for at least 10 days prior to methane and digestion measurements, and all animals were accustomed to handling.

Table 2 Sheep intakes, digestibility and methane production when fed contrasting diets. Data are means \pm S.D. with 6-8 sheep per treatment.

\begin{tabular}{|c|c|c|c|c|c|c|c|c|}
\hline \multirow{2}{*}{$\begin{array}{l}\text { Diet } \\
\text { FMR Trial } 1^{2}\end{array}$} & \multicolumn{2}{|c|}{$\begin{array}{l}\text { Dry matter intake } \\
\text { (g/day) }\end{array}$} & \multicolumn{2}{|c|}{$\begin{array}{c}\text { Dry matter } \\
\text { digestibility (\%) }\end{array}$} & \multicolumn{4}{|c|}{$\begin{array}{cc}\text { Methane production } \\
\mathrm{g} / \mathrm{kg} \mathrm{DMI}^{3} & \mathrm{~g} / \mathrm{kg} \text { DDMI }\end{array}$} \\
\hline & Mean & SD & Mean & SD & Mean & SD & Mean & SD \\
\hline Pasture & 1116 & 49.2 & 74.0 & 3.91 & 25.7 & 3.46 & 34.7 & 4.62 \\
\hline Lucerne & 1467 & 168.4 & 71.3 & 2.42 & 20.6 & 2.95 & 29.0 & 4.46 \\
\hline Sulla & 1500 & 71.3 & 72.8 & 2.56 & 17.5 & 2.20 & 24.1 & 3.13 \\
\hline Sulla/lucerne & 1674 & 93.3 & 71.1 & 1.83 & 19.0 & 1.21 & 26.7 & 1.71 \\
\hline \multicolumn{9}{|l|}{ FMR Trial $2^{2}$} \\
\hline Chicory & 1116 & 144.8 & 79.3 & 1.43 & 16.2 & 2.67 & 20.4 & 3.47 \\
\hline Red clover & 1763 & 71.6 & 75.6 & 1.08 & 17.7 & 2.87 & 23.4 & 3.92 \\
\hline Sulla & 1170 & 134.6 & 63.2 & 2.35 & 17.5 & 0.89 & 27.7 & 1.60 \\
\hline Chicory/S ulla & 1372 & 98.3 & 71.1 & 1.64 & 16.9 & 1.15 & 23.8 & 1.38 \\
\hline Chicory/Red clover & 1358 & 122.3 & 76.5 & 1.33 & 19.7 & 1.72 & 25.6 & 2.14 \\
\hline Lotus & 935 & 16.1 & 70.0 & 1.28 & 11.5 & 2.27 & 16.4 & 3.22 \\
\hline Lotus + PEG ${ }^{4}$ & 936 & 39.5 & 76.9 & 1.82 & 13.8 & 1.91 & 17.3 & 3.21 \\
\hline Dried lucerne & 897 & 0.0 & 58.0 & 1.40 & 15.7 & 4.29 & 27.1 & 8.01 \\
\hline
\end{tabular}

${ }^{1}$ Diets are defined in Table 1.

2 Forage mixed ration trials conducted in 2000 (Burke et al., 2002) and 2001 (Waghorn, unpublished).

${ }^{3}$ Abbreviations. DMI, dry matter intake; DDMI, digestible DM intake.

${ }^{4} \mathrm{PEG}$, polyethylene glycol removes effects of condensed tannins. 
The animals were given a permeation tube (approximately $30 \mathrm{~mm}$ long x $16 \mathrm{~mm}$ diameter) by mouth, which contained sulphur hexafluoride $\left(\mathrm{SF}_{6}\right)$, that was released at a calibrated rate of about $1 \mathrm{mg} /$ day over the methane measurement period. Aliquots of gas were collected adjacent to the nose of each sheep into evacuated yokes (about 1.0 litre at atmospheric pressure) over five consecutive $24 \mathrm{~h}$ periods. The concentrations of $\mathrm{SF}_{6}$ and methane in each sample were measured by gas chromatography and methane production calculated from the ratio of gases and the $\mathrm{SF}_{6}$ release rate (after background gas corrections) according to the method of Lassey et al. (2001). The methane production was averaged over five days and expressed in terms of feed intake.

Feed intakes were calculated from feeds offered and refused over a 7-day period in conjunction with methane measurements. Faeces collection enabled forage digestibility to be determined, so methane production could be expressed in terms of dry matter (DM) and digestible DM intakes (DDMI). Feed samples were analysed by near infrared reflectance spectrometry (NIRS) and where appropriate the concentration of CT was determined by butanol-HCl sequential extraction (Terrill et al. 1992).

Daily methane production was averaged over 5 days for each sheep and results are presented as absolute values or expressed in terms of dry matter intake and DDMI, as means with standard deviations for each treatment group. The effect of CT in lotus was determined by Students $t$ test, but comparisons between other treatments await further analyses of dietary constituents.

\section{Results}

The composition of the forage diets consumed by sheep are summarised in Table 1. All diets were of good quality, with crude protein concentrations ranging from $12.3 \%$ (chicory) to $26.4 \%$ (lotus) of DM and fibre from $12.7 \%$ (chicory) to $44.4 \%$ (pasture). The low fibre concentrations in all diets (except pasture) was complemented by high concentrations of readily fermentable constituents, and DM digestibility exceeded $70 \%$ for most feeds (Table 2). Condensed tannins were present in diets containing sulla and lotus, with negligible concentrations measured in chicory and in red clover.

Diets were fed ad libitum to all sheep except those fed lotus and dried and pelleted lucerne which were restricted to minimise selection of forage components. Intakes of sheep fed lotus and dried lucerne were about 1.2 times the maintenance requirement, with higher values for sheep fed diets based on pasture, lucerne, sulla, chicory and red clover.

When expressed in terms of DMI these diets resulted in a two-fold range in methane emissions, from a low value of $11.5 \mathrm{~g} / \mathrm{kg}$ DMI with lotus to $25.7 \mathrm{~g} / \mathrm{kg}$ DMI when good quality pasture was fed. Expression in terms of digestible DMI may improve the comparison between forages, insofar as the methane production relates to nutrients available for absorption. Again there was a twofold range in emissions ( $\mathrm{g} / \mathrm{kg}$ DDMI) with highest values for pasture (34.7), low values for chicory (20.4) and lowest values for lotus (16.4).

In the trial where lotus was fed, twice daily drenching with PEG (to remove effects of CT) showed that the CT was responsible for reducing emissions ( $\mathrm{g} / \mathrm{kg}$ DMI) by $16 \%(\mathrm{P}=0.07)$. The sulla diets, which contained 6.8 and $3.5 \% \mathrm{CT}$ in FMR Trials 1 and 2 also had low methane emissions (17.5 g/kg DMI). These methane emissions were similar to those from chicory which does not contain CT.

During the FMR Trial 1, the methane emissions ( $\mathrm{g} / \mathrm{kg}$ DDMI) for the sulla:lucerne mixture were midway between values for sulla and lucerne fed as sole diets. A similar relationship was evident in FMR Trial 2 where the sheep fed sulla/chicory produced methane emissions midway between each diet fed alone. However this relationship was not evident for the chicory/red clover combination where the mixed diet resulted in higher emissions (19.7 g/kg DMI) than either chicory (16.2 g/ $\mathrm{kg}$ DMI) or red clover (17.7) fed alone.

\section{Discussion}

These preliminary results summarise data from trials where the feed intake of sheep have been measured in conjunction with methane measurements. There are two important findings arising from these experiments. 1 . Methane emissions from fresh good quality forages can vary over a two-fold range, with the highest emissions coming from pasture. 2. Diets containing $\mathrm{CT}$ had lower levels of methane production and the presence of CT is associated with reduced methanogenesis.

We are not aware of comparable data from sheep fed the diets reported here (except for pasture), however trials with lactating cows have demonstrated substantial differences between pasture and Lotus corniculatus or sulla diets. Woodward et al. (2002) reported a similar methane production of $24.6 \mathrm{~g} / \mathrm{kg}$ DMI when pasture was fed compared to $19.5 \mathrm{~g} / \mathrm{kg}$ DMI with fresh sulla. An indoor trial with cows fed either pasture or lotus corniculatus silage resulted in very high methane emissions of $35.1 \mathrm{~g}$ and $26.9 \mathrm{~g} / \mathrm{kg}$ DMI for the respective feeds (Woodward et al. 2001).

The two-fold range in methane emissions from the current diets indicate that good opportunities for methane mitigation exist. Factors commonly associated with differences in methanogenesis include dietary fibre content, readily fermentable carbohydrate concentrations and rumen residence time (Johnson et al. 2000), so the 
high values from sheep fed pasture are probably a consequence of the high fibre concentration $(44.4 \%$ of DM; Table 1) relative to other feeds.

The impact of CT on methanogenesis is small but significant (a $16 \%$ reduction). In addition to the impact on methanogenesis, CTs have beneficial effects on ruminant nutrition and production such as the reductions in the incidence of bloat and lowered intestinal worm burdens (Waghorn et al. 1998). The mechanisms by which $\mathrm{CT}$ reduces methane emissions are not known, but may involve changes in microbial degradation in the rumen and/or direct and indirect effects on bacteria and methanogenic organisms (archaea).

Although the relative effects of different forages on methane emissions are similar to other reports, comparison between methane emissions by sheep fed pasture in this study $(25.7 \mathrm{~g} / \mathrm{kg}$ DMI; $34.7 \mathrm{~g} / \mathrm{kg}$ DDMI) with values for grazing lambs $(14.9-15.3 \mathrm{~g} / \mathrm{kg}$ DMI; Ulyatt et al. 1997) or grazing ewes $(20.1-31.5 \mathrm{~g} / \mathrm{kg}$ DDMI; Ulyatt et al. 2002) demonstrates substantial differences in estimates. The extent of the difference is especially clear when data from many of the legumes fed in this study also have higher values than those reported from sheep grazing pasture (Ulyatt et al. 1997, 2002; Judd et al. 1999; Lassey et al. 2002).

The reason(s) for differences in methane emissions between this and other studies needs to be identified because field values form the basis for New Zealand inventory calculations (Clark \& Ulyatt, 2002). Current estimates of methane production by sheep grazing pasture used to determine New Zealand GHG emissions (Clark \& Ulyatt, 2002) range from 20.8-30.4g/kg DDMI, for young and mature sheep respectively. The likelihood that selection of a higher quality diet from pastures, especially by young lambs is tenable (e.g. Hughes et al. 1984), but the methane production by lambs fed lucerne in this study would suggest diet selection by lambs grazing pasture could not be responsible for the difference between estimates. In fact the lambs in FMR Trials 1 and 2 consumed only $65-85 \%$ of feed on offer and there were good opportunities for diet selection.

Accurate measurement of intake is the basis for methane inventory calculations and for comparisons between this and other trials. However intake measurements from grazing animals are notoriously difficult and overestimates of intake from grazing studies (Ulyatt et al. 1997, 2002; Judd et al. 1999; Lassey et al. 2002) would contribute to lower values for methane production (per kg DMI). The data reported from indoor trials do enable accurate intake measurements, so differences between inventory measurements (Clark \& Ulyatt 2002) and results reported here do need to be elucidated. Most grazing studies and the FMR trials enabled ad libitum feed consumption, which may reduce methane emissions per unit feed intake relative to restricted intakes (of lotus and dried lucerne).

Other possible causes of differences between outdoor and indoor estimates such as $\mathrm{SF}_{6}$ accumulation in the sheep feeding bin (due to the density of $\mathrm{SF}_{6}$ and low air flows) would lower estimates of methane production and could not explain the differences between indoor and outdoor measurements.

The impact of CT and the likely influence of fibre on methane production reported in this study have important implications for future plant manipulation and breeding. Selection for increased DM digestibility have been successful in forage grasses and have been associated with improvements in animal performance (Casler \& Vogel 1999). Further testing is required to determine whether improved digestibility reduces methane emissions. International efforts to express $\mathrm{CT}$ in forage legumes such as lucerne, red and white clovers through genetic engineering are underway, however increasing dietary CT concentrations through inclusion of forages able to express CT (eg lotuses, sulla) are more likely to have benefits in the short-term. Selections for increased CT concentrations in white clover and red clover flowers are currently being evaluated for their impact on methane emissions in dairy cows. Other plant compounds are being assessed for their effect on methanogenesis and to determine the genetic variation present in New Zealand forages.

\section{Conclusions}

1. A twofold variation in methane emissions per unit of DM intake has been demonstrated for a range of forages with DM digestibilities of $70 \%$ or greater. High emissions from pasture are probably associated with the high fibre content.

2. Relative effects of methane production from contrasting forages fed to sheep are comparable to the ranges reported for dairy cows.

3. Methane production by sheep fed indoors in experiments reported here are substantially higher than those from grazing sheep, but the differences are not easily explained.

4. Condensed tannins have been shown to reduce methane emissions.

5. Dietary mitigation should include a variety of options, including the use of legumes in place of grasses, avoiding mature grasses and including forages containing condensed tannins.

\section{ACKNOWLEDGEMENTS}

The authors thank Keith Lassey (NIWA) for supply of the permeation tubes and the many people who contributed to running the experiments where methane was measured; German Molano, Jennifer Burke, Scott 
Waghorn, Adrienne Cavanagh, Luke Waghorn and Davanea Forbes.

\section{REFERENCES}

Burke, J.L.; Waghorn, G.C.; Brookes, I.M. 2002. An evaluation of sulla (Hedysarum coronarium) with pasture, white clover and lucerne for lambs. Proceedings of the New Zealand Society of Animal Production 62: 152-156.

Casler, M.D.;Vogel,K.P. 1999. Accomplishments and impact from breeding for increased forage nutritional value. Crop Science 39: 12-20.

Clark, H. 2001. Ruminant methane emissions: a review of the methodology used for national inventory estimations. A report prepared for the Ministry of Agriculture and Forestry. June 2001.

Clark, H.; Ulyatt, M.J. 2002. A recalculation of enteric methane emissions from New Zealand ruminants 1990-2000 with updated emission predictions for 2010. A report prepared for the Ministry of Agriculture and Forestry April 2002. Draft report.

Hughes, T.P.; Sykes, A.R.; Poppi, D.P. 1984. Diet selection of young ruminants in spring. Proceedings of the New Zealand Society of Animal Production 44: 109-112.

Johnson, D.E.; Johnson, K.A.; Ward, G.M.; Branine, M.E. 2000. Ruminants and other animals. pp. 112133. In: Ed. M.A.K. Khalil. Atmospheric Methane. Springer-Verlag.

Jones, W.T.; Mangan, J.L. 1977. Complexes of the condensed tannin of Sainfoin (Onobrychus viciifolia Scop.) with fraction 1 plant protein and with submaxilliary mucoprotein and their reversal by polyethylene glycol and $\mathrm{pH}$. Journal of the Science of Food and Agriculture 28: 126-136.

Judd, M.J.; Kelliher, F.M.; Ulyatt, M.J.; Lassey, K.R.; Tate, K.R.; Shelton, D.; Harvey, M.J.; Walker, C.F. 1999. Net methane emissions from grazing sheep. Global Change Biology 5: 647-657.

Lassey, K.R.; Walker, C.F.; McMillan, A.M.S.; Ulyatt, M.J. 2001. On the performance of SF6 permeation tubes used in determining methane emission from grazing livestock. Chemosphere - Global Change Science 3: 367-376.

Lassey, K.R.; Pinares-Patino, C.S.; Ulyatt, M.J. 2002.
Methane emission by grazing livestock: Some findings on emission determinants. Pp. 95-100. In: Eds J. van Ham, A.P.M. Baede, J. Williams-Jacobse. Non $\mathrm{CO} 2$ green house gases: Scientific understanding, control options and policy aspects Millpress, Rotterdam.

New Zealand Climate Change Project 2002. National Inventory Report. Greenhouse Gas Inventory 19902000. As reported April 2002. New Zealand Climate Change Project. Department of Prime Minister and Cabinet. Wellington, New Zealand.

Robertson, L.J.; Waghorn, G.C. 2002. Dairy industry perspectives on methane emissions and production from cattle fed pasture or total mixed rations in New Zealand. Proceedings of the New Zealand Society of Animal Production 62: 213-218.

Terrill, T.H.; Rowan, A.M.; Douglas, G.B.; Barry, T.N. 1992. Determination of extractable and bound condensed tannin concentrations in forage plants, protein concentrate meals and cereal grains. Journal of the Science of Food and Agriculture 58: 321-329.

Ulyatt, M.J.; Lassey, K.R.; Martin, R.S.; Walker, C.F.; Shelton, I.D. 1997. Methane emission from grazing sheep and cattle. Proceedings of the New Zealand Society of Animal Production 57: 130133.

Ulyatt, M.J.; Lassey, K.R.; Shelton, I.D.; Walker, C.F. 2002. Seasonal variation in the methane emission for dairy cows and breeding ewes grazing ryegrass-white clover pastures in New Zealand. New Zealand Journal of Agricultural Research: In press.

Waghorn, G.C.; Douglas, G.B.; Niezen J. H.; McNabb, W.C.; Foote, A.G. 1998. Forages with condensed tannins - their nutritive value for ruminants. Proceedings of the New Zealand Grassland Association 60: 89-98.

Woodward, S.; Waghorn, G.C.; Lassey, K.R.; Ulyatt, M.J. 2001. Early indications that feeding Lotus will reduce methane emissions from ruminants. Proceedings of the New Zealand Society of Animal Production 61: 23-26.

Woodward, S.L.; Waghorn, G.C.; Lassey, K.R.; Laboyrie, P.G. 2002. Feeding sulla (Hedysarum coronarium) reduces methane emissions from dairy cows. Proceedings of the New Zealand Society of Animal Production 62: 227-230. 